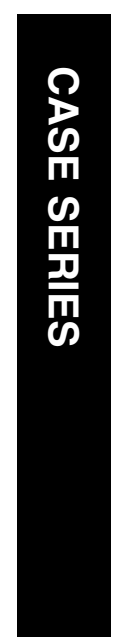

\section{Idiopathic isolated orbicularis weakness}

Vie 1 , MA Majid ${ }^{1}$, HM Husssin 1 , T Ung ${ }^{2}$ RM Manners², I Ormerod ${ }^{3}$, J Pawade Pand $^{4}$ and RA Harrad ${ }^{1}$ had entropion, although this was no longer
${ }^{1}$ Department of Ophthalmology, Bristol Eye Hospital, Bristol, UK

\section{${ }^{2}$ Department of} Ophthalmology, Southampton Eye Unit, Southampton, UK

${ }^{3}$ Department of Neurology, Frenchay Hospital, Bristol, UK

${ }^{4}$ Department of Histopathology, Bristol Royal Infirmary, Bristol, UK

Correspondence: RA Harrad, Bristol Eye Hospital, Lower Maudlin St, Bristol BS1 2L, UK Tel: $+44(0) 1173424174$; Fax: + 44 (0)117342 4721 E-mail: r.a.harrad@ bristol.ac.uk

Received: 15 September 2011

Accepted in revised form:

17 December 2011

Published online:

10 February 2012

\begin{abstract}
Purpose Orbicularis weakness is commonly associated with seventh nerve palsy or neuromuscular and myopathic conditions such as myotonic dystrophy and myasethenia gravis. We report four cases of idiopathic isolated orbicularis weakness.

Methods All four cases were female and the presenting symptoms of ocular irritation and epiphora had been present for over 7 years in three patients. All patients had lagophthalmos and three had ectropion. Three patients underwent full investigations which excluded known causes of orbicularis weakness. Two patients underwent oribularis oculi muscle biopsy and histological confirmation of orbicularis atrophy.

Results All patients underwent surgery to specifically address the orbicularis weakness with satisfactory outcomes and alleviation of symptoms in all cases. Isolated orbicularis weakness may be a relatively common entity that is frequently overlooked.

Conclusion Early recognition of this condition may lead to better management and prevent patients undergoing unnecessary surgical procedures.
\end{abstract}

Eye (2012) 26, 746-748; doi:10.1038/eye.2012.5;

published online 10 February 2012

Keywords: orbicularis weakness; VII nerve palsy; platinum lid implant

\section{Introduction}

We report four cases of idiopathic isolated orbicularis oculi muscle weakness. This condition is usually seen in the context of facial palsy, ${ }^{1}$ ocular myopathies ${ }^{2}$ or in generalised myopathies, such as myaesthenia gravis. ${ }^{3}$

\section{Case reports}

All patients were female and elderly. They presented with symptoms of discomfort and watering eyes. On examination, three patients had some degree of ectropion and case 3 earlier present when orbicularis weakness was noted. Case 3 was initially treated with Botox injections for entropion and then had bilateral lower lid wedge resections. All had between 4 and $6 \mathrm{~mm}$ of lagophthalmos and staining of the inferior cornea. There was no evidence of fatigue and eye movements were full. Orbicularis oculi muscles were very weak in all patients but there was no abnormality in any other cranial nerves. Other clinical details are documented in Table 1.

\section{Case 1}

Case 1 initially underwent surgery to correct apparent cicatricial ectropion, with failure to fully correct the defect. She then had symptoms of epiphora and discomfort for 7 years before she re-presented and was diagnosed with lagophthalmos and orbicularis weakness (Figure 1). Ocular lubricants alone were sufficient to control her symptoms and further surgery was not required.

Case 2

Case 2 had prompt recognition of orbicularis weakness causing lagophthalmos and epiphora, and surgery consisting of upper lid platinum weight insertion with lateral canthal slings resulted in symptomatic improvement and a good cosmetic result.

Case 3

Case 3 had initially presented with entropion. This is not usually associated with orbicularis weakness. It is likely that the orbicularis weakness developed after the entropion surgery. It is unlikely that Botox A injection had any lasting effect on orbicularis tone. Subsequent detection of orbicularis weakness resulted in appropriate correction: as cosmesis was not a particular priority, lateral tarsorrhaphies were performed, 
Table 1 Summary of clinical details of cases

\begin{tabular}{|c|c|c|c|c|}
\hline & Case 1 & Case 2 & Case 3 & Case 4 \\
\hline \multicolumn{5}{|l|}{ History } \\
\hline Age at presentation & 82 & 76 & 86 & 81 \\
\hline Symptoms and duration & $\begin{array}{l}\text { Epiphora, irritation, } \\
7 \text { years }\end{array}$ & $\begin{array}{l}\text { Epiphora, irritation, } \\
10 \text { years }\end{array}$ & Discomfort, 2 years & $\begin{array}{l}\text { Epiphora, discomfort, } \\
7 \text { years }\end{array}$ \\
\hline Previous surgery & $\begin{array}{l}\text { Bilateral tarsal } \\
\text { strip + skin graft }\end{array}$ & None & $\begin{array}{l}\text { Bilateral LL wedge excision. } \\
\text { Botox for entropion }\end{array}$ & None \\
\hline Co-morbidities & $\begin{array}{l}\text { R punctual } \\
\text { ectropion }\end{array}$ & $\begin{array}{l}\text { Mild paralytic } \\
\text { ectropion }\end{array}$ & None & Bilateral LL ectropion \\
\hline \multicolumn{5}{|l|}{ Examination } \\
\hline Bell's reflex & Moderate & Moderate & Poor & Poor \\
\hline Lagophthalmos & Present, $6 \mathrm{~mm}$ & Present, $5 \mathrm{~mm}$ & Present, $4 \mathrm{~mm}$ & Present, $4 \mathrm{~mm}$ \\
\hline Horizontal lid laxity & Absent & Moderate & Moderate & Present \\
\hline Corneal staining & Inferior staining & Inferior staining & Inferior staining & Inferior staining \\
\hline Fatigue & No & No & No & No \\
\hline Eye movements & Full & Normal & Full & Normal \\
\hline Orbicularis tone & Very poor & Poor & Very poor & Very poor \\
\hline Cranial nerve examination & Normal & Normal & Normal & Normal \\
\hline \multicolumn{5}{|l|}{ Investigations } \\
\hline Neurology opinion & Yes, normal & Yes, normal & Yes, normal & Patient refused \\
\hline MRI & Normal & Not requested & Normal & Patient refused \\
\hline Histology & Not requested & Not requested & $\begin{array}{l}\text { UL biopsy, } \\
\text { orbicularis atrophy }\end{array}$ & $\begin{array}{l}\text { LL biopsy, orbicularis } \\
\text { atrophy }\end{array}$ \\
\hline Blood results & $\begin{array}{l}\text { ACh receptor } \\
\text { antibody - ve }\end{array}$ & $\begin{array}{l}\text { ACh receptor } \\
\text { antibody - ve }\end{array}$ & $\begin{array}{l}\text { ACh receptor } \\
\text { antibody - ve }\end{array}$ & Patient refused \\
\hline \multicolumn{5}{|l|}{ Treatment } \\
\hline Surgical intervention & $\begin{array}{l}\mathrm{R} \text { excision of } \\
\text { diamond of conjunctiva }\end{array}$ & $\begin{array}{l}\text { Bilateral LTS, } \\
\text { Bilateral UL } \\
\text { platinum weights }\end{array}$ & Bilateral tarsorraphy & $\begin{array}{l}\text { Bilateral LTS and } \\
\text { one snip }\end{array}$ \\
\hline $\begin{array}{l}\text { Medical } \\
\text { intervention }\end{array}$ & Lubricants & Lubricants, initially & Lubricants & None \\
\hline
\end{tabular}

with good symptomatic relief. Orbicularis biopsy was obtained in this patient. Histology confirmed total atrophy of the orbicularis oculi.

\section{Case 4}

Case 4 had symptoms for 7 years and she had previously been reviewed on three occasions by a general ophthalmologist with regard to her ectropion, but the weakness of the orbicularis oculi muscles had not been noted. She had bilateral lower lid lateral tarsal slings and one snip procedures carried out under local anaesthetic with good results. A full thickness specimen of eyelid was sent for histological examination. This was reported as showing orbicularis oculi atrophy. Cross-sectional muscle fibre density was between 2 and 20 fibres per square millimetre compared with the normal density of 1000 fibres per square millimetre (Figure 2).

\section{Discussion}

There is a histological finding of orbicularis atrophy in two of our patients. Clinical features suggest that this may be the case in all four. Unfortunately, a tissue diagnosis was not possible in the other two patients. We do not think that these patients had myaesthenia gravis because in addition to the negative ACh receptor antibody test, no patients had ptosis or fatigue and the ocular movements were full in all four patients. The three patients who were seen by a neurologist were not thought to have myaesthenia gravis. No EMG was carried out. It was not attempted in cases 1 and 2, and it was refused in cases 3 and 4 . Where histological examination was done EMG would not have added any new information as no EMG trace would have been recordable. Although initial presentation was with a variety of different conditions, all four patients had isolated orbicularis weakness and lagophthalmos.

To our knowledge, isolated orbicularis weakness has not previously been reported. In view of the long delay between presentation and treatment in three of our cases it may not necessarily be a rare entity but rather an overlooked diagnosis, Given the surgical options available in the management of this condition and with good potential results for the patient, we believe that 

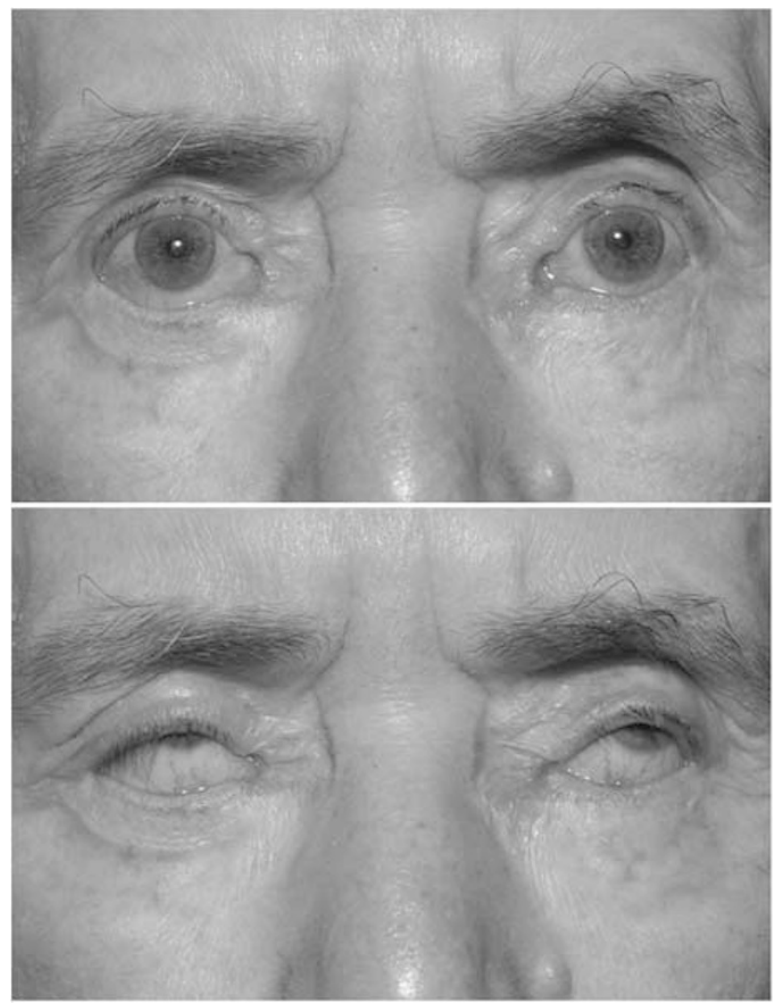

Figure 1 Case 1 has lagophthalmos on attempted lid closure with moderate Bell's reflex.

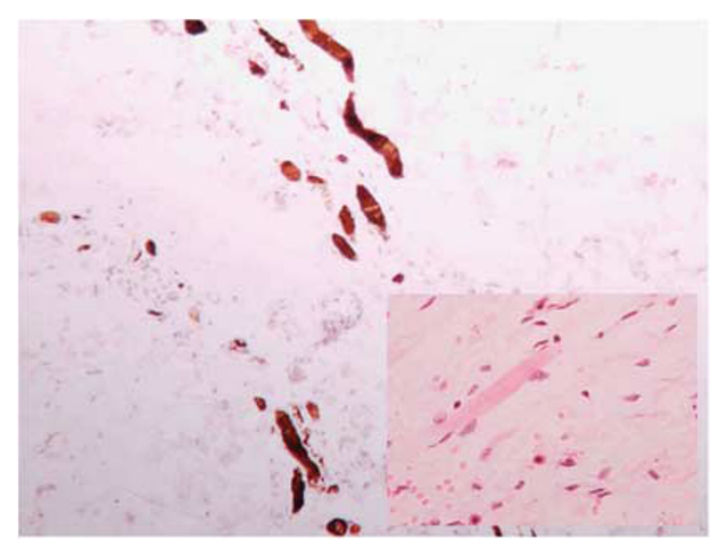

Figure 2 Immunohistochemical stain desmin highlights atrophic muscle fibres, inset shows a fibre at 400 magnification. recognition of the signs of orbicularis weakness will avoid unnecessary or inappropriate surgery and that assessment of orbicularis function should be part of the assessment of all patients with eyelid malposition. It is unfortunate that we were not able to fully investigate all four of our cases. All our patients were elderly and two were reluctant to undergo investigations or make further visits to hospital. In three patients orbicularis weakness had previously been overlooked in the clinic and three out of four patients had been symptomatic for 7 years or more.

Perhaps recognition of this condition will lead to the identification of more cases and a fuller characterisation of the disease in the future.

\section{Summary}

\section{What was known before}

- Weakness of the orbicularis oculi muscle is found in patients suffering from myopathy or facial palsy.

- An isolated orbicularis myopathy has not been previously described.

\section{What this study adds}

- This study describes isolated orbicularis oculi weakness for the first time.

- At present the condition seems to be idiopathic. Recognition of this condition can prevent inappropriate surgery.

- Orbicularis function should be assessed in all patients with eyelid malposition.

\section{Conflict of interest}

The authors declare no conflict of interest.

\section{References}

1 Leatherbarrow B, Collin JR. Eyelid surgery in facial palsy. Eye 1991; 5(5): 585-590.

2 Eshaghian J, Anderson RL, Weingeist TA, Hart MN, Cancilla PA. Orbicularis oculi muscle in chronic progressive external ophthalmoplegia. Arch Ophthalmol 1980; 98: 1070-1073.

3 Osher RH, Griggs RC. Orbicularis fatigue: the 'peek' sign of myasthenia gravis. Arch Ophthalmol 1979; 97(4): 677-679. 